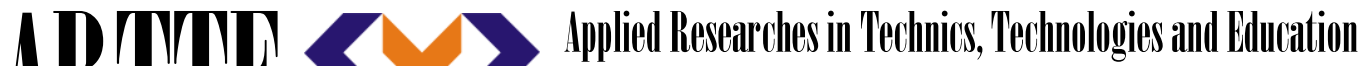 Journal of the Faculty of Technics and Technologies, Trakia University https://sites.google.com/a/trakia-uni.bg/artte/
}

\section{THE TRADITIONAL HARBOUR - THE SYMBOL OF ROMANIAN IDENTITY}

\author{
Lucia Vieru, Marcela Irovan \\ Faculty of Textiles and Poligraphy, Technical University of Moldova, Republic of Moldova \\ Blvd. Stefan cel Mare si Sfant, 168, MD 2004, Chisinau, Republic of Moldova \\ e-mail: marcela.irovan@gmail.com
}

\begin{abstract}
The Romanian traditional harbour is one of the basic elements of the material society, which developed at the same time with the Romanian people. Knowing the traditional suit allows understanding of the characters of the Romanian people's and it contributes to the definition of ethnicity. In recent years, the return to the ethnic motifs of the popular suit is considered as a necessity in the inspirational sphere, also as a cultural reference present within the fashion system. The ethnic elements are particularly important as a symbol and as an archetype in contemporary fashion. A stylized ethno shirt is an element of the continuity of traditional harbour and promotion of traditional values in a novel way. This work presents the results of a study on the analysis of the defining characteristics of the traditional clothing in the entire Romanian space and their valorisation in the contemporary costume. The folk clothing from the Romanian folkloric regions were analysed in detail following the categories: ornaments, colour chromatics and symbolism of the traditional harbour ornaments and we have presented the maps with the ethnographic areas according to the cuts of the shirts for women and men. We have identified the elements of the traditional clothing used in the modern ethno style clothing of contemporary designers. The results of the study were outlined in a collection of women's clothing products; the compositional and constructive solution presents ways of capitalizing on the elements of the traditional Romanian clothing in the wardrobe of the contemporary woman.
\end{abstract}

Keywords: ethno style, traditional harbour, the Romanian blouse.

\section{INTRODUCTION}

The Romanian traditional harbour is one of the basic elements of the material society, which developed at the same time with the Romanian people. Knowing the traditional harbour allows understanding of the characters of the Romanian people's and it contributes to the definition of ethnicity. In recent years, the return to the ethnic motifs of the popular costume is considered as a necessity in the inspirational sphere, also as a cultural reference present within the fashion system.

\section{THE TRADITIONAL CLOTHIG IN HISTORY}

The first historical evidence regarding the Romanian harbour dates back to the Neolithic period and the Bronze Age [1-6]. The evidence has been found in some clay statuettes showing women dressed in a shirt, handkerchiefs and sticks, found in the necropolis of Cárna in southern Oltenia. Another important archaeological source is the monuments "Tropaeum Traiani" from Adamclisi, Dobrogea and "Trajan's Column" in Rome, who show pictures of women and men dressed in wear that have the same characteristics as the popular harbour of today. (Figures 1-3)

In the fifteenth century, clothing was simple, was made of flax and hemp, the materials rarely being purchased from the fairs. Although the appearance and the texture were rather harsh, the pieces of clothing were animated and exhilarated by the ornaments due to the mastery and aesthetic taste of the weavers that enriched the costumes by colours.

IRTIIE Vol. 6, No. 2, 2018 ISSN 1314-8788 (print), ISSN 1314-8796 (online), doi: 10.15547/artte.2018.02.004 


\section{AR'T'TE}
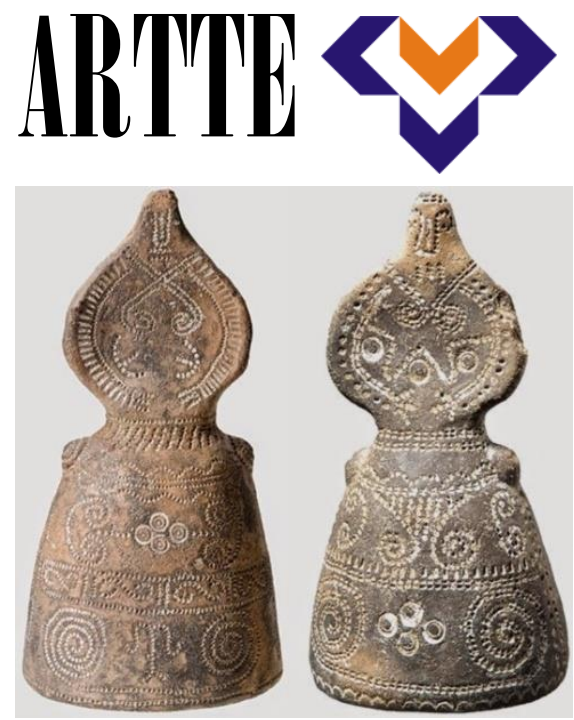

Figure 1. Statues found in the Carna necropolis, Oltenia

Ipplied Reseserir'hes in Technics, Technologies and Riduration

Journal of the Faculty of Technics and Technologies, Trakia University https://sites.google.com/a/trakia-uni.bg/artte/

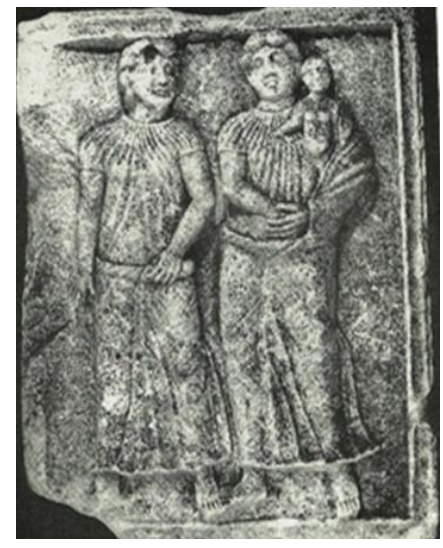

Figure 2. "Trophaeum Traiani“ Dobrogea

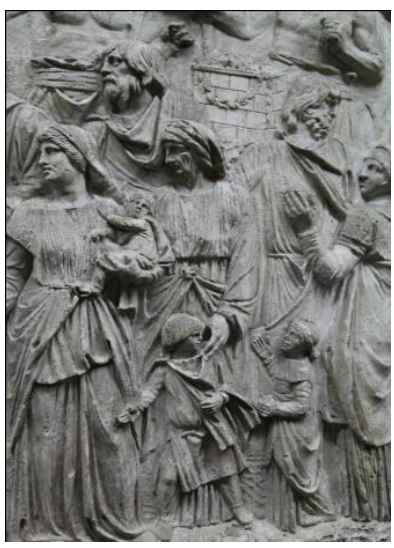

Figure 3. "Trajan's Column" Roma

The traditional harbour was made in all regions of the country of a white shirt - this is the basic piece of the Romanian costume - women wore the skirt and the men's trousers, and as footwear were the peasant sandals, named "opinci". The pieces that complement the women's harbour are the traditional skirt - "catrinţa", "fota", "vâlnice" and "oprege", and the men's suit are "chimirele" (some strips of leather worn at the waist). [1, 3]

Generally, the women's harbor consists of: a shirt, a skirt and a piece covering the side of the waist that is different from one region to another. It also has different names depending on its shape and area, so it can be: „catrintă”, „vâlnic”, „fotă”, „opreg”. These pieces are woven with wool, with simpler or more complicated ornamentation depending on the region. The shirts have the same ornamental parts, with some chromatic differences. A complement to the female port is the wide variety of head accessories that vary from region to region, from village to village. The value of these accessories depends on the beauty of fabrics and embroidery or other finery for this purpose. They are composed of: scarves, veils or crown of flowers. The other pieces of the female costume are the girdles, which are special artistic achievements. A feature of the women's costume in all regions is the use of the white colour, the flax, the hemp, and the wool. [1, 3]

The men's costume is simpler, consisting of a long shirt in the south and east of the country and shorter in the north and west, and the pants in the south and east are long and narrow and in the north and west of the country are shorter and wider. They are made of woven cloth at home. Over the shirt men put a belt or a leather chimney, depending on the region and occupation. In winter, wearing clothes from the baize, with beautiful ornaments, or leather jackets and vests. The shirt, as a basic element, is very important and presents, in all ethnographic regions, a special unit of structure. The shirt concentrates most of the decoration elements through its decor, marks the age difference, the context in which it is worn, the social state, etc. and determines the ornamental composition of the costume.

About the cut of the traditional costume can be said that, in the case of women, are used two basic principles for cutting and each of them in several variants. The "T" principle, as a sort of T-shirt, where the sleeves attach to the perpendicular 'stan' - this type of cut is universally valid, spread all over the world, considered to be the oldest due to its spreading. And the "Carpathian" cut, where the chest, back and two sleeves were tightened around the neck, wrinkled. A type of cut does not exclude the other. If we were living 200 years ago, each woman would have a few "T" shirts for work days, a wrinkled shirt (orange triangle) for church Sunday and a shirt with the other as a crown (cherry triangle) for Big holidays. The cut of the Romanian men's shirt is universally valid, used on many continents, from ancient times. The specialists call it "poncho", "tunic", we were called "right", "free", "old" "working", etc. Regardless of the name, the principle of cut is the same: the woven cloth results as a IRTITE Vol. 6, No. 2, 2018 ISSN 1314-8788 (print), ISSN 1314-8796 (online), doi: 10.15547/artte.2018.02.004 


\section{IRITIE}

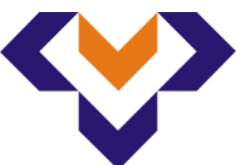

Ipplied Resseirlohes in Technics, Technologies and Bductation

Journal of the Faculty of Technics and Technologies, Trakia University https://sites.google.com/a/trakia-uni.bg/artte/

long roll, about $50 \mathrm{~cm}$ wide (slightly variable). This roll of cloth cuts to allow the head to pass and thus, symmetrically, cover the trunk - it was called "stan". For width were added the gussets and sleeves in the form of "T". There is no contour that a T-shirt now has; the sleeves are sewed by "stan" and for mobility, it was sewed a cloth square at the bottom junction - called "pava". The length of the shirt varies depending of the ethnographic region, fashion, time, age, event (the groom's shirts have always been longer). Men were, however, more conservative, less sensitive to fashion, and then their port was kept better, closer to the ancient one. (Figure 4) [1, 3, 4, 5]
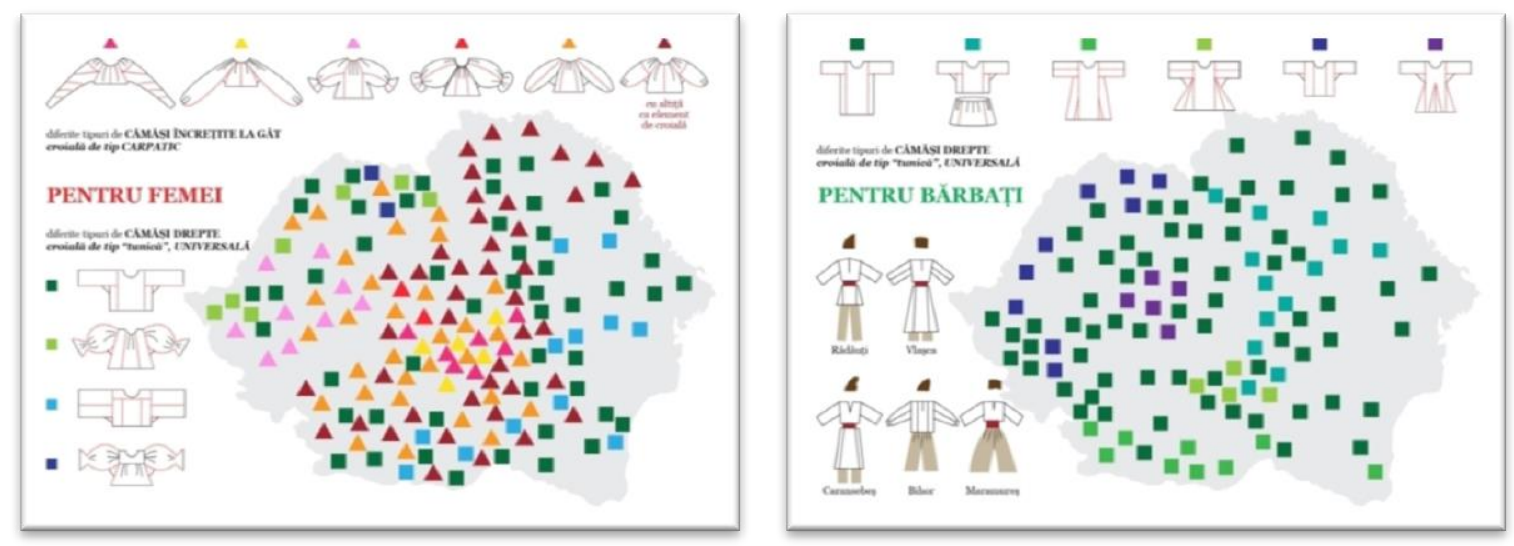

Figure 4. The maps with the ethnographic regions depending on the cuts of women's and men's shirts

The Romanian folk costume presents a unitary structure all over the country, the elements that make the difference from one area to another are those such as cut, folds at the neckline or sleeves, shape or colours. (Figure 5) [1-4]

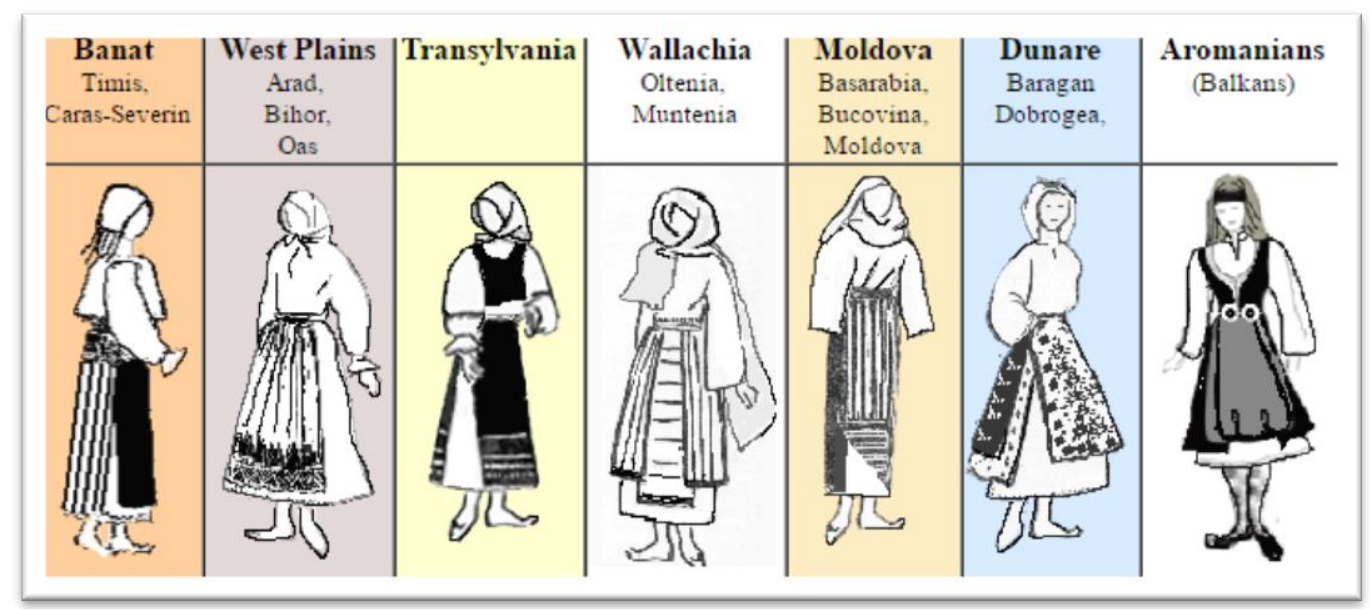

Figure 5. Traditional harbour according to the Romanian folkloric regions

They can simply be divided into seven folk regions, which are:

1) Transilvania;

2) Western Plains: Inferior Mureş plain, Crișul Negru plain, Crișul Alb plain, Crișul Repede plain, Someșului lower plain;

3) Banat, including the Meadow of Timis and Caras-Severin;

4) Wallachia, comprising Oltenia and Muntenia;

5) Lower Danube area, including Bărăganul, Dobrogea and southern Moldova;

IRTIIE Vol. 6, No. 2, 2018 ISSN 1314-8788 (print), ISSN 1314-8796 (online), doi: 10.15547/artte.2018.02.004 


\section{ARTTIE $Y$}

Ipplied Resseirlohes in Technics, Technologies and Bductation

Journal of the Faculty of Technics and Technologies, Trakia University https://sites.google.com/a/trakia-uni.bg/artte/

6) Moldova, including Bessarabia, Bukovina and Transnistria.

7) Romanians from the Balkan Peninsula, divided into 4 subgroups:

- Dacian-Romanians along the Romanian borders: Cadrilater (Bulgaria), Timoc (northwest Bulgaria and eastern Serbia), Vojvodina / Serbian Banat and Ukraine (especially in the Chernivtsi and Odessa regions).

- Istro Romanians from Istria, Croatia.

- Macedonians (or "Aromanians") from Albania, Bulgaria, Greece, Macedonia.

- Megleno Romanians from Greece and Macedonia.

Of course, from the regional differences category do not lack embroidery and ornaments that differ in shape and colour from area to area, depending of climate, relief, and the most precious item transmitted over time is wool and silk embroidery that adorns each piece of clothing in a unique way. (Figure 6) [6]
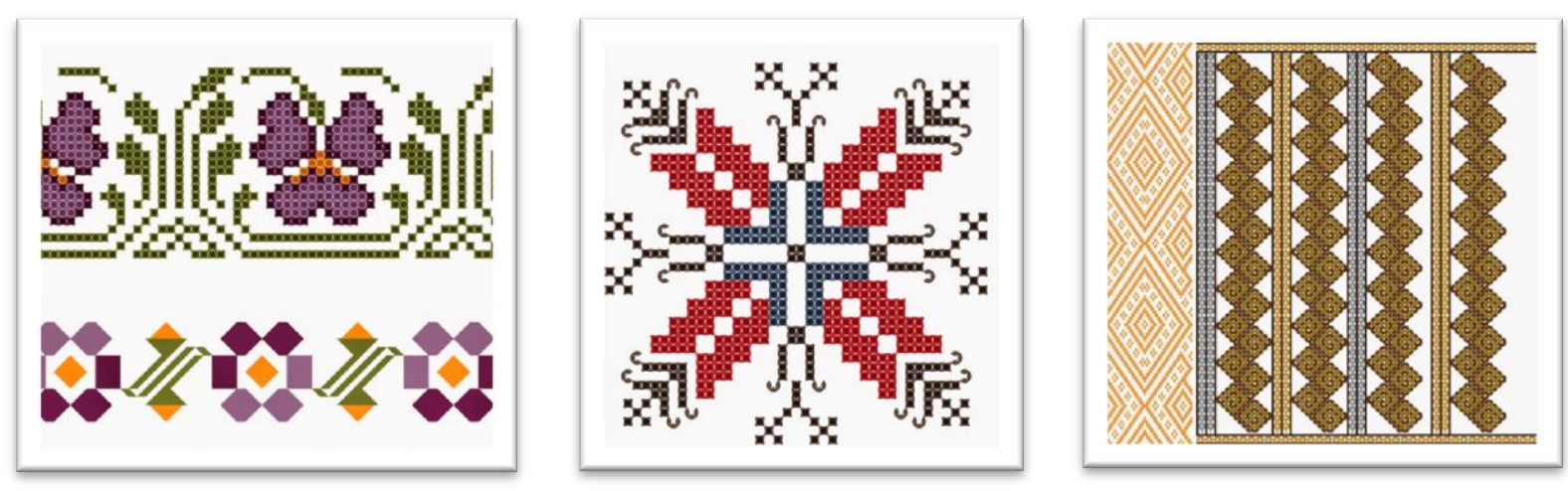

Figure 6. Traditional Romanian motifs used in embroidery of popular costumes

The ornamentation, where we observe the placement, the composition, the motives, we find it in different fields, emphasizing the line of the cut and highlighting the characteristic motifs in geometric or agrarian inspiration. Of the sewn and woven symbols on the cloth persists the sun and the stars, Earth and Heaven, many flowers, certain moments of human life, the transition to the world beyond. A special place is the symbol of the ornate and stylized cross in many forms, but also of other religious symbols: fish, Byzantine cross, ladder, vine, wheat spice, grape, peacock etc.

The chromatic (colour) of the motifs is another specific element of remarkable simplicity, using basic colours: red, black, dark brown, blue, certain tones of green and purple. The Romanian clothes impress with skill and diversity, distinguishing themselves through ethnogeographical areas of origin, through the periods in which they wore, their occupations, their social status or their age. In our traditional costume, we combine the useful with the beautiful. Traditional clothes are silent witnesses, but confessors of the faith and piety of our people. Our forefathers have not only been concerned with the making of wreaths and the diversification of the execution techniques or the materials used, but also with their special symbolism. Through the motifs sewn with needle and thread on canvas, the housewives gave to the traditional clothes profound symbols, by which the bearer of the shirt, the vest, or the girdle wore the entire universe, thus recalling, symbolically, all the mythology and cosmogony of the Dacians.

\section{THE USE OF THE TRADITIONAL COSTUME IN THE CREATIONS OF LOCAL AND INTERNATIONAL DESIGNERS}

Nowadays, the return to the ethnic motifs of the traditional harbour is considered as a necessity in the inspirational sphere, also as a cultural reference present within the fashion system. Through this return to the motives and ethnic elements, persist the importance of IRTIIE Vol. 6, No. 2, 2018 ISSN 1314-8788 (print), ISSN 1314-8796 (online), doi: 10.15547/artte.2018.02.004 


\section{ART'TlE $Y^{2}$}

Ipplied Resseirlohes in Technics, Technologies and Bductation

Journal of the Faculty of Technics and Technologies, Trakia University https://sites.google.com/a/trakia-uni.bg/artte/

cultural and social archetypes developed over an important historical time, archetypes that have preserved their meaning and essence to this day continue to exist. Ethnic elements are of particular importance as a symbol and as an archetype in contemporary fashion.[2,7]

The analysis of these forms of cultural expression supports the conclusion that the reuse of these elements determines the creation of products of great effect in contemporary fashion. In this context, the source of inspiration is important, but also the presence of a pertinent way of reapplying and reinventing these elements. But until a coat develop into a fashionable product, it crosses every stage of a process, sometimes difficult, to assert in the field of international clothing design. Although contemporary designers work according to a vision, resorting to an extensive range of styles and using current technological methods, cyclically, they return to traditional techniques and ethnic folk motifs, transforming them and resizing them, integrating them into contemporary space. [2, 7]

The French designer, Philippe Guilet, who came into contact with the traditional Romanian port, paid homage to the country through the collection "100\% Ro Prejudices" (Figure 7). After many months of research, discussions with various craftsmen and a great deal of dedication, he had everything to organize the presentation and design of clothing. Thus, the biggest $100 \%$ Romanian haute couture project was born.

Joseph Altuzarra, the French designer holding the American brand Altuzarra, was inspired by the Romanian costume for the Resort 2015 collection (Figure 8). The collection includes colourful outfits, blouses that resemble the Romanian shirt and ethnic skirt with ethno prints.

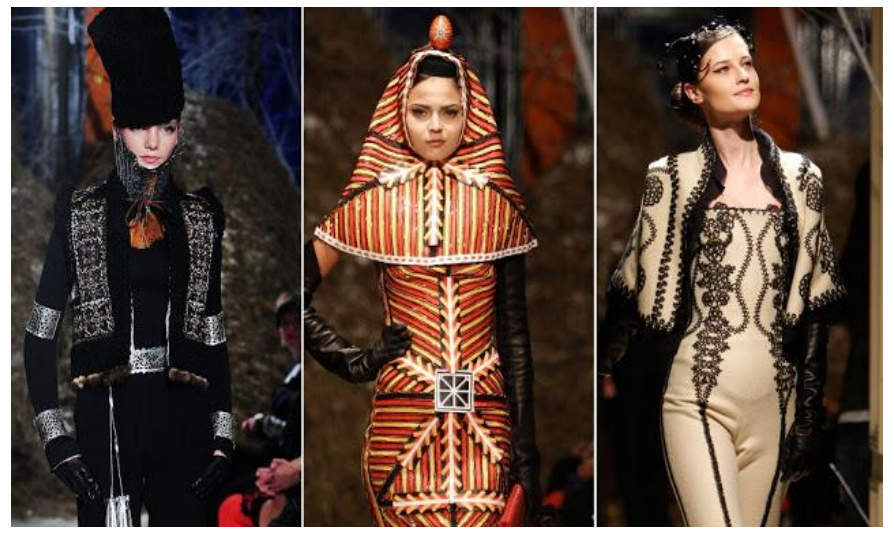

Figure 7. Collection "Prejudice 100\% Ro"
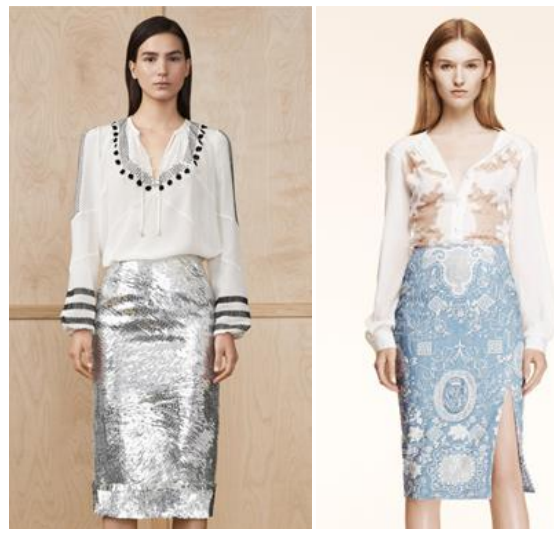

Figure 8. Resort Collection 2015

Today, the wearing of the traditional suit has become a true ethno trend. It is very touching to see a couple of young people who prefer to go to weddings in traditional clothes on the wedding day and and all the guests join with them and they come dressed in traditional clothes as well. There are many Romanian designers who have developed collections highlighting the return of the traditional costume to trends, but this "trend" has never disappeared, although it is only now that power is felt (Figure 9). Among them there are:

- Adrian Oianu, one of the most appreciated Romanian designers and one of the creators proudly inspired by the traditional Romanian costume, amazed his followers with three collections: "Blowing to the waist", "Joy" and "Romanian Punk". Both collections have as their source the Romanian costume, the clothes having manually embroidered on vests and collars.

- The "Lost" collection, presented by the Romanian designer Dorin Negrău, has proposed to the contemporary society clothes inspired by the traditional costume from the Bihor area. The main element of the collection is even the popular costume made 50 years ago by the designer's grandmother.

IRTIIE Vol. 6, No. 2, 2018 ISSN 1314-8788 (print), ISSN 1314-8796 (online), doi: 10.15547/artte.2018.02.004 


\section{ART'TE $Y$}

Ipplied Resseirl ches in Technics, Technologies and Bductation

Journal of the Faculty of Technics and Technologies, Trakia University https://sites.google.com/a/trakia-uni.bg/artte/

- Valentina Vidrascu - a Romanian designer known for the collections inspired by the Romanian harbour. She successfully reinterpreted the Roman shirt, but also a decadent version of the bridal dress. "We reinterpret the folk suit, giving a new identity to clothing such as the shirt, the vest, the skirt, the girdle. The special interventions in each collection are made using traditional techniques such as embroidery, weaving, crochet and goblet.
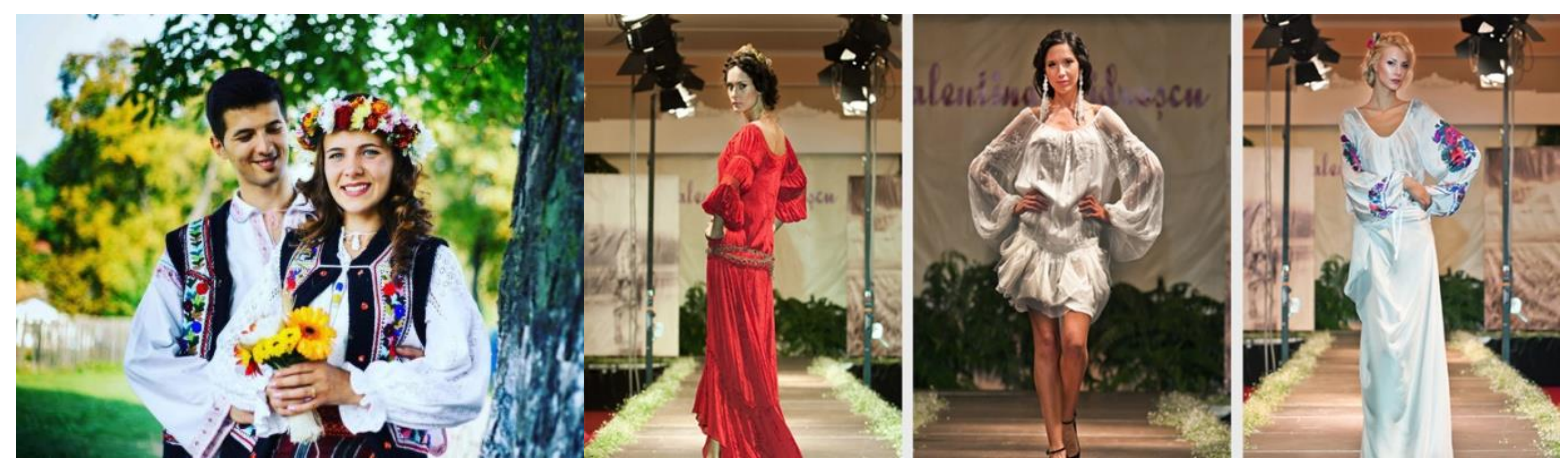

Figure 9. The elements of the traditional costume used in modern ethno clothing

\section{RESULTS}

The study's results were outlined in a collection of three women's clothes, consisting of blouses and trousers, with the introduction of elements characteristic of the traditional harbour (Figure10).
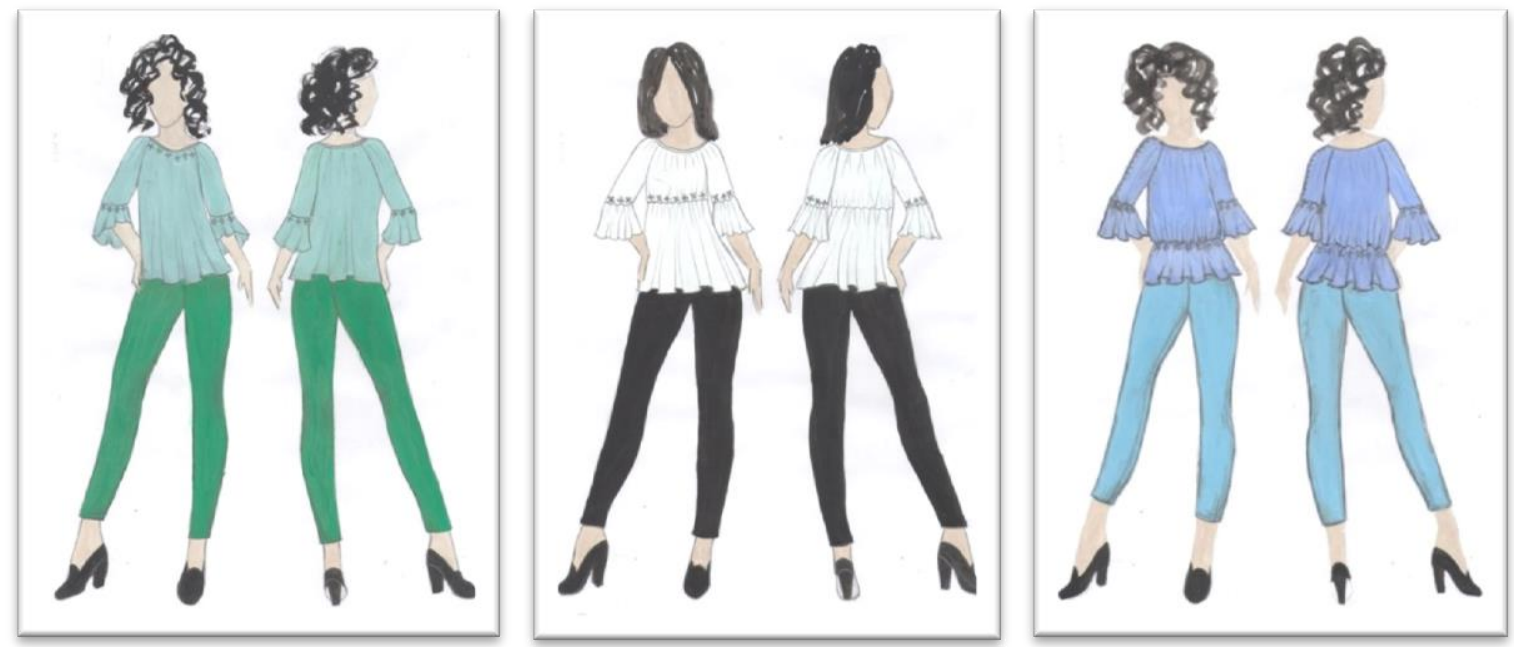

Figure 10. Women's clothes with traditional harbour elements

The shirt of the first model has front and back sides cut diagonally in trapezoidal form, the shape of the neck and sleeves remain stable just like the classic cut of an ordinary traditional shirt. The embroidery elements are located in the neckline and the upper part of the bellshaped cuff. The cuff is cut in the form of "sun" with the front face shorter than the back. The second blouse consists of the top, front and back, which is cut similar to the top of the first model, and the bottom of the blouse is flared, formed by wrinkling. The third full-blouse has a lightweight shape, made up of front and back parts, which are cut to the pattern of one and two, and the lower part forms by creasing a basque from a strip of cut material of the same length with the cuff. We have chosen geometric embroidery elements, which have a blued look rather than a "loaded" one. The trousers for all three sets are classical, with a high waist,

IRTTEE Vol. 6, No. 2, 2018 ISSN 1314-8788 (print), ISSN 1314-8796 (online), doi: 10.15547/artte.2018.02.004 
formed from the front and back. The chromatic colours of shirts and trousers are in a harmony of cold colours. The turquoise colour of the blouse of the first set completes perfectly with the green of the pants. The second set combines the classic black and white. In the third set there are two blue shades. The blouses are made of cotton mixed with viscose and trousers are made of gabardin. We got three ethno style sets, which remind, especially the blouses of the traditional harbour through the cut and embroidery elements.

\section{CONCLUSIONS}

Everyone must have a ethnic shirt or ethnic dress in the wardrobe for the simple reasons that such a type of clothing takes you out of any situation regardless of the event, is easily associated with any piece of clothing (skirt, trousers) or accessory, and last but not least, is the continuity of promoting port and traditional values in a new way.

It has come to a day dedicated to traditional Romanian shirts and our traditional harbour June 24, on the day of Sânziene. A commendable initiative, whom was founded just a few years ago, has just become an international event, because it is celebrated everywhere in the world, where Romanians live. Practically, in our day it is customary for the wearer's coat, wherever it may be found, to contain at least the basic element of the traditional suit, the blouse or the shirt. We are witnessing an unprecedented resurrection of Romanian traditions, of their place and role in everyday life, it giving hope that in the future there will be no forgetting or renegade history and culture. But, in addition to this chance, the phenomenon of "emancipation" of the traditional suit and, along with it, of the secular traditions also involves a risk: to sum up the whole movement to a simple "trend" that can be easily demolished, replaced by another. Therefore, in addition to making and wearing the traditional harbor, we must also "dress" with a culture of it, its spiritual and historical significance, understanding that he represents the quintessence of what ancestors lived and felt: our traditional costume has developed since the finalization of the Romanian ethnogenetic process, in specific historical and economic conditions, with its own ethnic. Without being wrong, we can say with all conviction that our Romanian port represents the emanation of the essence of spirituality of the soul of the people, open to those who want to feel its pulse, to understand and to deepen its mysteries with millennial age. Basic elements of spiritual and material culture, traditional clothing offers direct references to the way of life, thought and activity of the ancestors, but also about their creative power, their beliefs and their way of manifestation.

That's why the traditional harbor is a reverberation of the ancestral belief, a symbol of Romanian identity.

\section{REFERENCES}

[1] Buzilă V. Costumul popular din Republica Moldova. Ghid practic. Chișinău, 2011, p. 170. http://unesdoc.unesco.org/images/0021/002110/211085ron.pdf.

[2] http://www.romanianmuseum.com/ROMANESTE/RomaniaFolk.html.

[3] Enachescu M., Cantemir A.. Portul popular românesc. / Ediție îngrijită și cuvânt înainte de C.D. Zeletin. București: Editura Meridiane, 1971, p. 169.

[4] Işănoni D. Costumul românesc de patrimoniu. - Patrimony Romanian costume. / Doina Işfănoni, Paula Popoiu; ed.: Cori Simona Ion, Corina Firuţă; trad. eng.: Virginia Barghiel; foto: Cori Simona Ion. București: Alcor Edimpex, 2007, p. 146.

[5] Lupşan E. Portul popular. București: Editura Didactică și Pedagogică, 2006, p. 91.

[6] Postolachi E. Tinerețea portului străbun. Revista Moldova, 1987, Nr. 2, p. 16-17.

[7] Balan S., Tutunaru I., Irovan M., Andrieș D. Elaborarea noilor modele de produse vestimentare pentru femei utilizând elemente specifice portului popular moldovenesc. Creativitate. Tehnologie. Marketing: CTM 2014: Al 3-lea Simpozion internațional, 31 oct.01 noiembrie, Culegere de articole, ISBN 978-9975-80-853-8. pag. 171-176.

IRTIIE Vol. 6, No. 2, 2018 ISSN 1314-8788 (print), ISSN 1314-8796 (online), doi: 10.15547/artte.2018.02.004 